\title{
Potentiality of waste human hair towards removal of chromium(VI) from solution: kinetic and equilibrium studies
}

\author{
Naba Kumar Mondal ${ }^{1} \cdot$ Sambrita Basu ${ }^{1}$
}

Received: 22 September 2018 / Accepted: 11 March 2019 / Published online: 21 March 2019

(c) The Author(s) 2019

\begin{abstract}
Industrial and agricultural activities discharges huge amount of hazardous pollutants that lead to massive environmental pollution and health hazards. Keratin is a fascinating protein and useful biopolymer, which is usually found in wool, human hair, nails, feathers, etc. The present research deals with the potentiality of human hair towards removal of hexavalent chromium from aqueous solution through batch mode. The adsorbent was characterized by $\mathrm{pH}_{\mathrm{ZPC}}$ and SEM study. $\mathrm{The} \mathrm{Cr}(\mathrm{VI})$ adsorption was studied with the help of different process parameters, viz. initial concentration, contact time, adsorbent dose, $\mathrm{pH}$, and temperature. Results revealed that $\mathrm{Cr}(\mathrm{VI})$ adsorption by human hair was highly $\mathrm{pH}$ sensitive. Maximum $\mathrm{Cr}(\mathrm{VI})$ was adsorbed from water at $\mathrm{pH}$ 1.0. Study of temperature effect on chromium adsorption confirmed the endothermic behaviour of the process. On the other hand, thermodynamic properties were also calculated and found that physisorption was dominant with activation energy of $0.385 \mathrm{~kJ} \mathrm{~mol}^{-1}$. Kinetic study revealed that pseudo-second-order model was followed by the adsorption process. Adsorption equilibrium was analysed with Langmuir, Freundlich, and Dubinin-Radushkevich isotherm models. Results showed that the adsorption system followed both Langmuir and Freundlich isotherms with Langmuir adsorption capacity of $9.852 \mathrm{mg} \mathrm{g}^{-1}$, which was compared with other adsorbents and observed that the performance of the present adsorbent is better than others. Finally, it can be concluded that human hair could be an alternative chief low-cost waste material for decontamination of heavy metals from an aqueous medium.
\end{abstract}

Keywords Human hair $\cdot$ Hexavalent chromium $\cdot$ Adsorption $\cdot$ Isotherm $\cdot$ Keratin $\cdot$ Kinetics

\section{Introduction}

Heavy metal-induced pollution has remarkably increased due to excessive discharges of heavy metals from various industries including metallurgical, steel manufacturing, fertilizer, including sponge iron, etc. (Rajapaksha et al. 2018; Gu et al. 2015). Among the different heavy metals, chromium has been specially attracted due to its both mutagenic and carcinogenic activities (Kazakis et al. 2017). Chromium exists in various oxidation states including $\mathrm{Cr}$ (III), which is mainly presence in the aqueous medium under acidic condition $(\mathrm{pH}$

Electronic supplementary material The online version of this article (https://doi.org/10.1007/s13201-019-0929-5) contains supplementary material, which is available to authorized users.

Naba Kumar Mondal

nkmenvbu@gmail.com

1 Environmental Chemistry Laboratory, Department of Environmental Science, The University of Burdwan, Burdwan, West Bengal, India
3.5) as $\mathrm{Cr}^{3+}, \mathrm{Cr}(\mathrm{OH})^{2+}, \mathrm{Cr}(\mathrm{OH})_{3}$ and $\mathrm{Cr}(\mathrm{OH})_{4}^{-}$. However, under oxidizing conditions $\mathrm{Cr}$ exists as $\mathrm{Cr}(\mathrm{VI})$-oxoanion species such as $\mathrm{HCrO}_{4}^{-}(\mathrm{pH} 4-6)$ or $\mathrm{CrO}_{4}{ }^{2-}(\mathrm{pH} \mathrm{8-10)}$. The mobility of hexavalent chromium is higher than trivalent chromium in the aqueous medium (Brose and James 2013). The lower oxidation state of chromium can be precipitated after reduction of $\mathrm{Cr}(\mathrm{VI})$ (Hsu et al. 2009). In the soil enriched with $\mathrm{Fe}$ and $\mathrm{Mn}$ oxides, $\mathrm{Cr}(\mathrm{VI})$ can be adsorbed through sorption process under acidic condition (Zhang et al. 2017). $\mathrm{Cr}(\mathrm{VI})$ is a powerful oxidant which can oxidize the biomolecules and subsequently induce toxicity. The usual toxicity symptoms are necrosis, irritation of the gastrointestinal mucosa, etc. Hexavalent chromium is also known for its mutagenic and carcinogenic nature (Eleftheriou et al. 2015). Chromium can enter into the cell in the form of chromate $\left(\mathrm{CrO}_{4}{ }^{2-}\right)$ through sulphate uptake channel. After insertion, $\mathrm{Cr}(\mathrm{VI})$ interacts with reducing biomolecules through formation of labile intermediates, and possibly this labile intermediate interacts with biomolecules including the 
bases of DNA (Feng et al. 2017). This may cause the main toxicity of hexavalent chromium.

Various technologies are available in the literature for removal of hexavalent chromium from the aqueous medium such as coagulation, precipitation, osmosis, and electrodialysis. However, all the above technologies have serious limitation due to high operational cost and generation of huge sludge. The above difficulties can be removed by using a cost-effective and high-performance technique known as adsorption (Liu et al. 2019).

Previous literature (Manjuladevi et al. 2018; Khulbe and Matsuura 2018; Mohan et al. 2005) highlighted a large number of adsorbents, which are mainly used for removal of $\mathrm{Cr}(\mathrm{VI})$ from aqueous solution. Various adsorbents such as biochar, activated carbon, and clay have been investigated (Rajapaksha et al. 2018; Nethaji and Sivasamy 2014; Khan et al. 2010). However, none of the above adsorbents showed good performance towards removal of $\mathrm{Cr}(\mathrm{VI})$ from aqueous medium. Therefore, there is a tremendous need of a suitable adsorbent, which should be easily available and greener one.

Hair is a complex tissue of animal body. It contains many chemicals which are mainly played as a main structural component. Human hair consists of proteins (65-95\%), water, lipids, pigment, and trace elements (Ekop and Eddy 2010). Human hair is normally disposed as solid waste generated after hair cutting. These hairs can be used as an excellent adsorbent towards removal of heavy metals from aqueous solutions (Tan et al. 1985). Previous literature (Ingole et al. 2014) highlighted that human hair is an excellent adsorbent which removes oil from wastewater. However, there is not enough information regarding the efficacy of human hair to remove chromium from aqueous medium under varying different operating variables $(\mathrm{pH}$, initial concentration, dose, contact time, temperature, etc.).

\section{Materials and methods}

\section{Collection and preparation of adsorbent}

Hair sample was collected from the different saloons of Burdwan town. After collection, the hair was washed with shampoo and dried in shade followed by cut into very small $1 \mathrm{~mm}$ in size by using electric cutter and stored in plastic airtight container for further use.

\section{Characterization of adsorbent}

(a) $\mathrm{pH}$ of zero-point charge

$\mathrm{pH}$ of zero-point charge was measured by following the method adopted by Bhaumik and Mondal (2015) through solid addition method. A series of $100-\mathrm{mL}$ conical flask contains $50 \mathrm{~mL}$ of $0.1 \mathrm{M} \mathrm{KNO}_{3}$ in each flask. The $\mathrm{pH}$ of solution was adjusted from 1.0 to 10.0 by using $0.1(\mathrm{~N}) \mathrm{NaOH}$ or $0.1(\mathrm{~N}) \mathrm{HCl}$. Then, $0.2 \mathrm{~g}$ of hair was added to each flask and capped properly and sets into a shaker for $48 \mathrm{~h}$ and then filtered and measured the final $\mathrm{pH}$ of the solution.

(b) Scanning electron micrography (SEM)

The SEM (HITACHI, S-530, Scanning Electron Microscope and ELKO Engineering) study was performed with both before and after adsorption of hexavalent chromium in a fixed resolution to understand morphological change of human hair.

\section{Preparation of $\mathrm{Cr}(\mathrm{VI})$ solution}

A stock solution of $\mathrm{K}_{2} \mathrm{Cr}_{2} \mathrm{O}_{7}$ was prepared by exactly weighing $0.2828 \mathrm{~g}$ of potassium dichromate in $250 \mathrm{~mL}$ double distilled water and finally diluted to $1 \mathrm{~L}$ which is equivalent to the strength of $100 \mathrm{mg} \mathrm{L}^{-1}$. The $\mathrm{pH}$ of the experimental solution was adjusted by using $0.1(\mathrm{~N}) \mathrm{HCl}$ or $0.1(\mathrm{~N}) \mathrm{NaOH}$ solution.

\section{Estimation of $\mathrm{Cr}(\mathrm{VI})$}

After performing adsorption study, the percentage of removal is calculated by using the following equation (Eq. 1):

$\operatorname{Removal}(\%)=\frac{\left(C_{0}-C_{\mathrm{e}}\right)}{C_{0}} \times 100$

where $C_{0}$ and $C_{\mathrm{e}}$ are the initial and final concentrations of $\mathrm{Cr}(\mathrm{VI})$. The chromium concentration was measured by atomic adsorption spectrometry (LABINDIA, AS8000).

The adsorption capacity of human hair is calculated by the following equation (Eq. 2):

$q_{\mathrm{m}}(\mathrm{mg} / \mathrm{g})=\frac{\left(C_{0}-C_{\mathrm{e}}\right) \times V}{M}$

where $V$ and $M$ are the volume of the solution in litter and weight of solute taken in gram.

\section{Regeneration study}

Regeneration of the exhausted adsorbent can be done by 0.1 (M) $\mathrm{NaOH}$ solution. The saturated adsorbent was taken in a conical flask containing $0.1 \mathrm{M} \mathrm{NaOH}$ and placed in a magnetic starrer at $200 \mathrm{rpm}$ for $30 \mathrm{~min}$. After first cycle of filtration, the same thing has been done for the next $30 \mathrm{~min}$. 


\section{Results and discussion}

\section{Adsorbents characterization}

\section{Analysis of $\mathrm{pH}_{\mathrm{ZPC}}$}

From the $\mathrm{pH}_{\mathrm{ZPC}}$ study, it is clear that all the three adsorbents showed different zero-point charge. The zero-point charge of human hair is 6.9363 (Fig. S1). The charges on the surface of adsorbents depend on these $\mathrm{pH}_{\mathrm{ZPC}}$ values below and above the $\mathrm{pH}_{\mathrm{ZPC}}$; the surface of the adsorbents changes to positive and negative charges, respectively. However, at the $\mathrm{pH}_{\mathrm{ZPC}}$ point, adsorbent surface has no charge at al. As per the literature, chromium species present in different oxy-anionic forms such as $\mathrm{CrO}_{4}^{=}, \mathrm{HCrO}_{4}^{-}$or $\mathrm{Cr}_{2} \mathrm{O}_{7}^{=}$at acidic $\mathrm{pH}$ and the present experiment suggests that all the three adsorbents showed maximum $\mathrm{Cr}(\mathrm{VI})$ removal at acidic $\mathrm{pH} 1$ and it is below the $\mathrm{pH}_{\mathrm{ZPC}}$ value. Therefore, it can be suggested that $\mathrm{Cr}(\mathrm{VI})$ adsorption is favourable when the surface of the adsorbent is positive. Almost similar observation was reported by the earlier researchers (Saha et al. 2013).

\section{SEM study}

Figure 1a exhibits the scanning electron micrography of human hair before adsorption of hexavalent chromium. From Fig. 1a, it is clear that human hair is layer-like structure without any deformation. However, after adsorption of $\mathrm{Cr}(\mathrm{VI})$, the surface of human hair is very rough in nature (Fig. 1b). This is perhaps due to effective interaction of $\mathrm{Cr}(\mathrm{VI})$ with protein

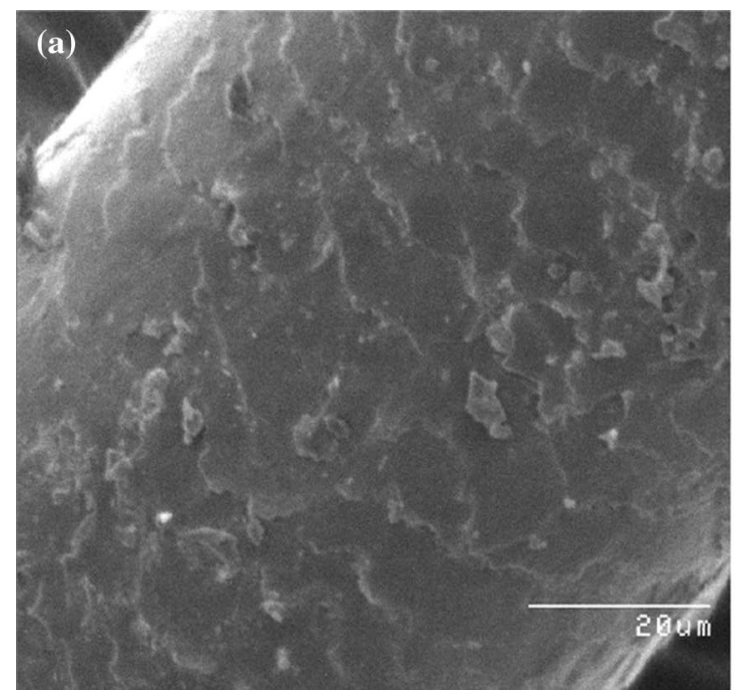

structure ( $\alpha$-keratin) of hair (Zhang et al. 2018; Mahdavian 2014).

\section{Effect of initial concentration}

The removal of $\mathrm{Cr}(\mathrm{VI})$ from the aqueous solution by using human hair was studied by varying initial concentration of $\mathrm{Cr}(\mathrm{VI})$ from 10 to $30 \mathrm{mg} \mathrm{L}^{-1}$, and the results are depicted in Fig. 3. From figure S2, it is clear that for a fixed amount of adsorbent $(0.02 \mathrm{~g}), \mathrm{pH}(1)$, contact time (30 $\mathrm{min})$ and temperature $\left(40{ }^{\circ} \mathrm{C}\right)$, percentage of $\mathrm{Cr}(\mathrm{VI})$ removal increases with increasing initial concentration from 10 to $30 \mathrm{mg} \mathrm{L}^{-1}$. Therefore, the present results highlighted that the adsorbents support to bind the metal at a higher concentration. Results also revealed that at lower concentration (up to $15 \mathrm{mg} \mathrm{L}^{-1}$ ) the $\mathrm{Cr}(\mathrm{VI})$ is not so impressive. However, at $20 \mathrm{mg} \mathrm{L}^{-1}$, the percentage of $\mathrm{Cr}(\mathrm{VI})$ removal reached to $81.82 \%$. Almost similar enhanced rate of adsorption of $\mathrm{Zn}^{2+}$ and $\mathrm{Pb}^{2+}$ by human hair was recorded with increasing concentration (Ekop and Eddy 2010). It was also noted that with increasing initial concentration from 10 to $30 \mathrm{mg} \mathrm{L}^{-1}$, the adsorption capacity of the $\mathrm{Cr}(\mathrm{VI})$ in human hair increased from 11.175 to $62.365 \mathrm{mg} \mathrm{g}^{-1}$ (Fig. S2). This enhancement of adsorption with increasing initial concentration of $\mathrm{Cr}(\mathrm{VI})$ is attributed by the fact that the increase of driving force and also overcome the mass transfer resistance of metal ions between solid-liquid interphase (Khambhaty et al. 2009).

\section{Effect of adsorbents dose}

The influences of adsorbent dosage $(0.01,0.05,0.1,0.5$ and $1.0 \mathrm{~g}$ human hair) on the adsorption of $\mathrm{Cr}(\mathrm{VI})$ ions at $40{ }^{\circ} \mathrm{C}$ are shown in figure $\mathrm{S} 3$. With the increase in biosorbent dose

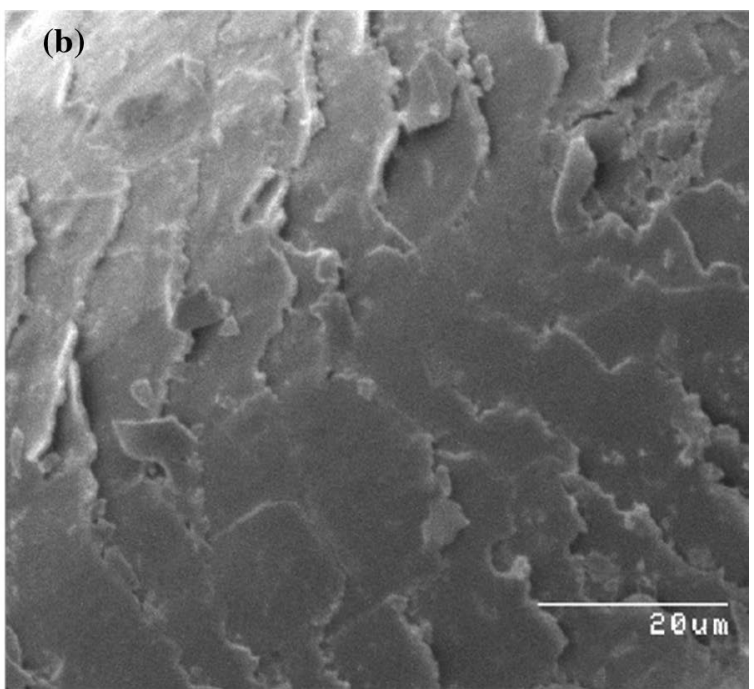

Fig. 1 a Human hair before $\mathrm{Cr}(\mathrm{VI})$ adsorption $(\times 1500)$ and $\mathbf{b}$ human hair after $\mathrm{Cr}(\mathrm{VI})$ adsorption $(\times 1500)$ 
from 0.01 to $1.0 \mathrm{~g} / 50 \mathrm{ml}$, the percentage of $\mathrm{Cr}(\mathrm{VI})$ removal increased from 57.43 to $98.77 \%$. This is probably due to the availability of active binding sites where $\mathrm{Cr}(\mathrm{VI})$ ions adsorbed (Mohamed et al. 2017; Khambhaty et al. 2009). On the other hand, further increase in adsorbent dose did not cause any improvements towards adsorption of $\mathrm{Cr}(\mathrm{VI})$. This is perhaps due to the establishment of equilibrium between the ions bound to the sorbent and those remaining unabsorbed in the solution. The study results also revealed that after reaching an optimum dose, no further improvement towards removal of $\mathrm{Cr}(\mathrm{VI})$ was recorded. This can be attributed by the fact that the surface of newly added adsorbent will no longer active due to agglomeration or overlapping (Meng et al. 2017).

\section{Effect of pH}

$\mathrm{pH}$ is an important factor that strongly influenced the heavy metal adsorption (Gupta et al. 2001; Park et al. 2005a). Figure S4 illustrates the percentage of adsorption capacity with the variation of $\mathrm{pH}$ from 1 to 10 . The maximum and minimum $\mathrm{Cr}(\mathrm{VI})$ removal was recorded at $\mathrm{pH} 1$ and 10 , respectively, for initial concentration of $30 \mathrm{mg} \mathrm{L}^{-1}$. At low $\mathrm{pH}$, the availability of $\mathrm{H}^{+}$ions increases near the adsorbent surface, and subsequently, the ionic species of $\mathrm{Cr}(\mathrm{VI})$ undergo electrostatic interaction with positive surface. But at higher $\mathrm{pH}$, adsorbent surface changes to negative due to excessive $\mathrm{OH}^{-}$ions and subsequently $\mathrm{Cr}(\mathrm{VI})$ biosorption got decreased (Dehghani et al. 2016). This observation is very much consistent with the earlier work where $\mathrm{Cr}(\mathrm{VI})$ was removed by various adsorbents (Bari and Abraham 2001; Park et al. 2005b; Tewari et al. 2005).

\section{Effect of contact time}

The adsorption of chromium ions on human hair was investigated as a function of contact time (10-60 min) at constant initial concentration $\left(30 \mathrm{mg} \mathrm{L}^{-1}\right)$ and fixed temperature $55^{\circ} \mathrm{C}$. As figure $\mathrm{S} 5$ shows, the removal efficiency of $\mathrm{Cr}(\mathrm{VI})$ ions from aqueous solution increases rapidly up to $50 \mathrm{~min}$. The high removal efficiency at the initial stages is probably due to the availability of large number of active adsorption sites which saturated with time. The maximum removal (99.96\%) was reported at $50 \mathrm{~min}$. However, after $50 \mathrm{~min}$, the removal decreased to $98.5 \%$ at $60 \mathrm{~min}$. Therefore, this has been considered as the optimum contact time for adsorption of $\mathrm{Cr}(\mathrm{VI})$. Almost similar efficiency towards removal (99.66\%) of $\mathrm{Cr}(\mathrm{VI})$ by quaternized chitosan microspheres at 50 min was reported by Hua et al. (2016).

\section{Effect of temperature}

Previous literature (Wang et al. 2008; Khambhaty et al. 2009) suggested that temperature is an initial factor for removal of heavy metal from aqueous solution through adsorption mechanism. Therefore, the present experiment was conducted to examine the effect of temperature on removal of $\mathrm{Cr}(\mathrm{VI})$ from aqueous solution (Fig. S6). Figure S6 shows that with increasing temperature from 30 to $55^{\circ} \mathrm{C}$, the percentage of $\mathrm{Cr}(\mathrm{VI})$ removal increases from $85.86 \%$ to $97.8 \%$. That means percentage of $\mathrm{Cr}(\mathrm{VI})$ removal favoured with temperature. Therefore, this observation clearly suggests that $\mathrm{Cr}(\mathrm{VI})$ interaction with the human hair is absolutely endothermic one. Almost similar temperature dependency of $\mathrm{Pb}^{2+}$ and $\mathrm{Zn}^{2+}$ removal by human hair was reported by Ekop and Eddy (2010).

\section{Isotherm study for human hair}

On the basis of experimental results, biosorption isotherm was used to understand the interaction pattern of $\mathrm{Cr}(\mathrm{VI})$ with human hair, at equilibrium. The Langmuir model was based on the assumption that the adsorbate only attached to the specific sites of the adsorbent surface, suggesting that the uptake of adsorbate is absolutely unilayer without interaction between adsorbate molecules. The following form of Langmuir equation (Eq. 3) is traditionally applied:

$q_{\mathrm{e}}=\frac{q_{\mathrm{m}} b C_{\mathrm{e}}}{1+b C_{\mathrm{e}}}$

Equation (Eq. 4) can be conveniently transformed to the following linearized form:

$\frac{C_{\mathrm{e}}}{q_{\mathrm{e}}}=\frac{1}{q_{\mathrm{m}} b}+\frac{C_{\mathrm{e}}}{q_{\mathrm{m}}}$

where $q_{\mathrm{m}}$ is the maximum uptake ( $\mathrm{mg} \mathrm{g}^{-1}$ ), $q_{\mathrm{e}}$ the uptake capacity at equilibrium $\left(\mathrm{mg} \mathrm{g}^{-1}\right), C_{\mathrm{e}}$ the equilibrium solution concentration $\left(\mathrm{mg} \mathrm{L}^{-1}\right), \mathrm{b}$ the Langmuir constant $(\mathrm{L} / \mathrm{mg})$. The output of Langmuir constant $\left(q_{\mathrm{m}}\right.$ and $\left.b\right)$ and correlation coefficient $\left(R^{2}\right)$ are presented in Table 1 . As it can be seen from Table 1, the adsorption isotherm of $\mathrm{Cr}(\mathrm{VI})$ exhibited Langmuir behaviour, which indicates a monolayer adsorption. The adsorption of $\mathrm{Cr}(\mathrm{VI})$ by human hair is well-fitted with both Freundlich and Langmuir models; therefore, the Langmuir-Freundlich equation was also applied to the data sets. Basically the combined equation of Langmuir-Freundlich is known as Sips model. Table 1 also highlights that the Freundlich constant $K_{\mathrm{F}}$ and $n$ are $13.62(\mathrm{mg} / \mathrm{g})(\mathrm{L} / \mathrm{mg})^{1 / \mathrm{n}}$ and 1.134 , respectively. Therefore, these values indicate that the adsorption capacity and adsorption intensity both are favourable (Bhaumk et al. 2012). Similarly, the higher value of regression coefficient of Freundlich isotherm suggested the multi-layer adsorption of $\mathrm{Cr}(\mathrm{VI})$ onto human hair (Varvala et al. 2016). Almost similar Cr(VI) removal was recorded by Berihum (2017) using coffee husk carbon. The 
Table 1 Isotherm data for $\mathrm{Cr}(\mathrm{VI})$ adsorption using human hair

\begin{tabular}{lllll}
\hline Adsorption isotherm & Equations & Parameters & Values & $R^{2}$ \\
\hline Langmuir isotherm & $\frac{1}{q_{\mathrm{e}}}=\frac{1}{q \max K_{\mathrm{L}} C_{\mathrm{e}}}+\frac{1}{q \max }$ & $q_{\max }$ & 9.852 & 0.912 \\
Freundlich isotherm & $\log q_{\mathrm{e}}=\log K_{\mathrm{F}}+\frac{1}{n} \log C_{\mathrm{e}}$ & $K_{\mathrm{F}}(\mathrm{mg} / \mathrm{g})(\mathrm{L} / \mathrm{mg})^{1 / \mathrm{n}}$ & 0.338 & 13.62 \\
D-R isotherm & $\ln q_{\mathrm{e}}=\ln q_{\max }-\frac{1}{2 E^{2}}$ & $q_{\max }$ & 1.134 & 0.992 \\
& $*\left[R T \ln \left(1+\frac{1}{C_{\mathrm{e}}}\right)^{2}\right]$ & $E\left(\mathrm{KJ} \mathrm{mol}^{-1}\right)$ & 18.857 & 0.721 \\
& & & \\
& & & \\
\hline
\end{tabular}

\begin{tabular}{lllll}
\hline Kinetics model & Equations & Parameters & Values & $R^{2}$ \\
\hline Pseudo-first order & $\log \left(q_{\mathrm{e}}-q_{t}\right)=\log q_{\mathrm{e}}-\frac{K_{1} t}{2.303}$ & $q_{\mathrm{e}}\left(\mathrm{mg} \mathrm{g}^{-1}\right)$ & 4.015 & 0.9266 \\
& & $K_{1}\left(\mathrm{~min}^{-1}\right)$ & $21.23 \times 10^{2}$ & \\
Pseudo-second order & $\frac{t}{q_{t}}=\frac{1}{K_{2} q_{\mathrm{e}}^{2}}+\frac{1}{q_{\mathrm{e}}}$ & $q_{\mathrm{e}}\left(\mathrm{mg} \mathrm{g}^{-1}\right)$ & 1.5081 & 1.00 \\
& & $K_{2}\left(\mathrm{~g} \mathrm{mg}^{-1} \mathrm{~min}^{-1}\right)$ & 2.3779 & \\
Intraparticle diffusion & $q_{t}=K_{1} t^{1 / 2}+C$ & $K_{1}\left(\mathrm{~min}^{-1 / 2}\right)$ & 58.672 & 0.7747 \\
& & $C$ & 82.041 & \\
\hline
\end{tabular}

Table 2 Summary of parameters for various kinetic models by human hair
Langmuir-Freundlich equation (Eq. 5) can be expressed in the following way:

$q_{e}=\frac{q_{s} b_{s} C_{e}^{1 / n_{s}}}{1+b_{s} C_{e}^{1 / n_{s}}}$

Equation (Eq. 6) can be easily linearized as:

$\ln \left[\frac{q_{s}}{q_{\mathrm{e}}}-1\right]=-\ln b_{s}-\frac{1}{n_{s}} \ln C_{\mathrm{e}}$

\section{Adsorption kinetics for human hair}

The adsorption kinetics of $\mathrm{Cr}(\mathrm{VI})$ adsorption onto human hair was evaluated by pseudo-first-order, pseudo-secondorder and intraparticle diffusion kinetic equations and the constant values depicted in Table 2. From Table 2, it is clear that the experimental data are well-fitted with pseudo-second-order kinetics model with very high correlation coefficient $\left(R^{2}=1.00\right)$.

On the other hand, pseudo-first-order and intraparticle diffusion model are moderately fitted with the experimental data (Table 2). These results suggest that the adsorption onto the adsorbent at specific temperature was best presented by the pseudo-second-order equation, which is based on the assumption that the rate-limiting step may be the chemisorption (Aksu 2001). Song et al. (2016) reported the same observation for removal of toxic chromium by wheat straw and Euatorium adenophorum. Very recently, Campos et al. (2019) reported that core-shell bimagnetic nanoadsorbents can remove hexavalent chromium from aqueous solutions and it followed the pseudo-second-order model.
Table 3 Thermodynamics parameters for adsorption of $\mathrm{Cr}(\mathrm{VI})$ by human hair

\begin{tabular}{llll}
\hline $\begin{array}{l}\text { Tempera- } \\
\text { ture }(\mathrm{K})\end{array}$ & $\Delta G^{\circ}\left(\mathrm{KJ} \mathrm{mol}^{-1}\right)$ & $\Delta H^{\circ}\left(\mathrm{KJ} \mathrm{mol}^{-1}\right)$ & $\Delta S^{\circ}\left(\mathrm{KJ} \mathrm{mol}^{-1}\right)$ \\
\hline 303 & -420.216 & & \\
313 & -725.165 & $+3 \times 10^{-4}$ & +67.0149 \\
318 & -726.246 & & \\
323 & -2044.332 & \\
328 & -1151.517 & \\
\hline
\end{tabular}

\section{Thermodynamic study for human hair}

The thermodynamic parameters for the obtained equilibrium data on temperature variation by the use of equations (Eqs. 7-9) were evaluated. The equilibrium constant $K_{\mathrm{c}}$ is calculated based of $C_{\mathrm{Ae}}$ and $C_{\mathrm{e}}$ values:

$K_{\mathrm{c}}=\frac{C_{\mathrm{Ae}}}{C_{\mathrm{e}}}$

where $C_{\mathrm{Ae}}$ indicates adsorption in $\mathrm{mg} \mathrm{L}^{-1}$ at equilibrium and $C_{\mathrm{e}}$ is the equilibrium concentration of the metal in $\mathrm{mg} \mathrm{L}^{-1}$. The respective values of other thermodynamic parameters such as $\Delta H^{\circ}$ and $\Delta S^{\circ}$ were obtained from the slope and interpret of the plot of $\log K_{\mathrm{c}}$ against $1 / T$ (Eq. 8), revealing that the values of free energy $\left(\Delta G^{\circ}\right)$ at different temperatures are obtained using Eq. 9.

$\log K_{\mathrm{c}}=\frac{\Delta S^{\circ}}{2.303 R T}-\frac{\Delta H^{\circ}}{2.303 R T}$

where $T$ is the temperature in Kelvin and $\mathrm{R}$ is the gas constant $\left(\mathrm{KJ} \mathrm{mol}^{-1} \mathrm{~K}^{-1}\right)$. 
The entire results for the thermodynamic parameters are presented in Table 3. From Table 3 , it is clear that both $\Delta H^{\circ}$ and $\Delta S^{\circ}$ are positive; the positive value of $\Delta H^{\circ}$ for $\mathrm{Cr}(\mathrm{VI})$ removal by human hair confirms that the adsorption process is endothermic in nature and positive $\Delta S^{\circ}$ indicates the adsorption process is spontaneous. However, the spontaneity of chromium adsorption is also supported by the free energy value at different temperatures (Table 3), according to equation (Eq. 9).

$\Delta G^{\circ}=-R T \ln K_{\mathrm{c}}$

Results indicate that there is more negative value of $\Delta G$ at higher temperatures. That is the adsorption of $\mathrm{Cr}(\mathrm{VI})$ by human hair is favourable at higher temperatures. This is perhaps because the adsorption reaction is absolutely endothermic in nature. Almost similar results were reported by Ekop and Eddy (2010) for removal of $\mathrm{Zn}^{2+}$ and $\mathrm{Pb}^{2+}$ ions from aqueous solution by using human hair.

\section{Regeneration study}

In wastewater treatment process, the regeneration of exhausted adsorbent is an extremely important factor (Mohamed et al. 2017). The saturated adsorbent was washed several times with 0.1 (M) $\mathrm{NaOH}$ followed by distilled water and dried in shade. Then, activated adsorbent was again used for removal of $\mathrm{Cr}(\mathrm{VI})$ from aqueous solution. The present results highlighted that about $69 \% \mathrm{Cr}(\mathrm{VI})$ can be removed by regenerated adsorbent. The current research (Su et al. 2019) demonstrated that exhausted activated carbon with hexavalent chromium can be regenerated by $1 \mathrm{M} \mathrm{HCl}$.

\section{Comparison with other published keratinous substances}

Hexavalent chromium adsorption along with other heavy metals by various keratinous substances has been compared

Table 4 Comparison of heavy metal uptake by various keratinous substances

\begin{tabular}{llll}
\hline Adsorbents & Heavy metal & $\begin{array}{l}\text { Adsorption } \\
\text { capacity } \\
\left(\mathrm{mg} \mathrm{g}^{-1}\right)\end{array}$ & References \\
\hline $\begin{array}{l}\text { Human hair } \\
\text { Goat hair }\end{array}$ & $\mathrm{Pb}^{2+}$ & 33.0 & Mahdavian (2012) \\
Ship hair & & 24.0 & \\
Wool & $\mathrm{Cr}^{6+}$ & 40.0 & \\
Modified wool & $\mathrm{Fe}^{2+}$ & 37.0 & Dakiky et al. (2002) \\
& $\mathrm{Zn}^{2+}$ & 11.0 & McNeil (2001) \\
Wool fibres & $\mathrm{As}^{5+}$ & 0.22 & $\begin{array}{c}\text { Hassan and Davies- } \\
\text { McConchie } \\
\end{array}$ \\
Human hair & $\mathrm{Cr}^{6+}$ & 9.852 & \begin{tabular}{c} 
Present work \\
\hline
\end{tabular}
\end{tabular}

with respect to the results of adsorption capacity, and it is presented in Table 4. From Table 4, it is clear that wool showed greater than four times of $\mathrm{Cr}(\mathrm{VI})$ adsorption than human hair. The performance of animal hair exhibited higher adsorption capacity of heavy metals than human hair. Table value also revealed that human hair is better performance for lead removal than chromium. Hassan and DaviesMcConchie (2012) demonstrated that wool fibre has lower adsorption capacity for $\operatorname{arsenic}(\mathrm{V})$.

\section{Conclusion}

The present study results revealed that human hair was effective in the removal of $\mathrm{Cr}(\mathrm{VI})$ from aqueous medium. The efficacy of human hair was tested through batch study with variation of initial concentration, adsorbent dose, contact time $\mathrm{pH}$, and temperature. The equilibrium of $\mathrm{Cr}(\mathrm{VI})$ adsorption was nicely fitted with Langmuir and Freundlich isotherms with adsorption capacity of $9.852 \mathrm{mg} \mathrm{g}^{-1}$. The pseudo-second-order kinetics is wellfitted with regression coefficient 1.00 . Thermodynamic of $\mathrm{Cr}(\mathrm{VI})$ adsorption by human hair is endothermic in nature. Finally, it can be concluded that human hair could be an inexpensive material for removal of hexavalent chromium from aqueous solution. Further study can be done towards removal of other metals from aqueous solutions.

Acknowledgements This work was supported by authors' own laboratory expenses, and the entire work was performed in the form of MSc dissertation in the year 2016-2017. Authors express their sincere thanks to all the faculty members of both Environmental Science and Biotechnology Departments, The University of Burdwan, Burdwan for their academic help. Authors also wish to extend their heartfelt thanks to all the officials including technical staff of University Science Instrumentation, The University of Burdwan, Burdwan, for their active help during sample analysing, specially scanning electron micrograph study.

\section{Compliance with ethical standards}

Conflict of interest The authors declare that they have no conflict of interest.

Open Access This article is distributed under the terms of the Creative Commons Attribution 4.0 International License (http://creativeco mmons.org/licenses/by/4.0/), which permits unrestricted use, distribution, and reproduction in any medium, provided you give appropriate credit to the original author(s) and the source, provide a link to the Creative Commons license, and indicate if changes were made.

\section{References}

Aksu Z (2001) Equilibrium and kinetic modeling of Chromium (II) biosorption by $C$. vulgaris in a batch system temperature: effect of temperature. Sep Purf Technol 21:285-294 
Bari RT, Abraham E (2001) Biosorption of Cr(VI) from aqueous solution by Rhizopus nigricans. Bioresour Technol 79:73-81

Berihum D (2017) Removal of chromium from industrial wastewater by adsorption using coffee husk. J Mater Sci Eng 6:331. https:// doi.org/10.4172/2169-0022.1000331

Bhaumik R, Mondal NK (2015) Adsorption of fluoride from aqueous solution by a new low-cost adsorbent: thermally and chemically activated coconut fibre dust. Clean Technol Environ Policy 17:2157-2172. https://doi.org/10.1007/s10098-015-0937-6

Bhaumk R, Mondal N, Das B, Roy P, Pal KC, Das C, Banerjee A, Dutta JK (2012) Eggshell powder as an adsorbent for removal of fluoride from aqueous solution: equilibrium, kinetic and thermodynamic studies. Eur J Chem 9(3):1457-1480

Brose DA, James BR (2013) Hexavalent chromium reduction by tartaric acid and isopropyl alcohol in mid-Atlantic soils and the role of Mn(III, IV)(hydr)oxides. Environ Sci Technol 47:12985-12991

Campos AFC, de Oliveira HAL, da Silva FN, da Silva FG, Coppola P, Aquino R, Mezzi A, Depeyrot J (2019) Core-Shell Bimagnetic Nanoadsorbents for Hexavalent Chromium Removal from Aqueous Solutions. J Hazard Mater 362:82-91. https://doi.org/10.1016/j. jhazmat.2018.09.008

Dakiky M, Khamis M, Manassra A, Mer'eb M (2002) Selective adsorption of chromium VI in industrial wastewater using low-cost abundantly available adsorbents. Adv Environ Res 6:533-540

Dehghani MH, Sanaei D, Ali I, Bhatnagar A (2016) Removal of chromium(VI) from aqueous solution using treated waste newspaper as a low-cost adsorbent: kinetic modeling and isotherm studies. J Mol Liq 215:671-679

Ekop AS, Eddy NO (2010) Thermodynamic study on the adsorption of $\mathrm{Pb}^{2+}$ and $\mathrm{Zn}^{2+}$ from aqueous solution by human hair. Eur J Chem 7(4):1296-1303

Eleftheriou EP, Adamakis IDS, Panteris E, Fatsiou M (2015) Chromiuminduced ultrastructural changes and oxidative stress in roots of Arabidopsis thaliana. Int J Mol Sci 16:15852-15871

Feng M, Yin H, Peng H, Liu Z, Lu G, Dang Z (2017) Hexavalent chromium induced oxidative stress and apoptosis in Pycnoporus sanguineus. Environ Pollut 228:128-139

Gu YL, Xu WH, Liu YG, Zeng GM, Huang JH, Tan XF, Jian H, Hu X, Li F, Wang DF (2015) Mechanism of Cr(VI) reduction by Aspergillus niger: enzymatic characteristic, oxidative stress response, and reduction product. Environ Sci Pollut Res 22:6271-6279

Gupta VK, Shrivastava AK, Jain N (2001) Biosorption of Cr(VI) from aqueous solutions by green algae Spirogyra sp. Water Resour 35:4079-4085

Hassan MM, Davies-McConchie JF (2012) Removal of arsenic and heavy metals from potable water by bauxsol immobilized onto wool fibers. Ind Eng Chem Res 51:9634-9641

Hsu NH, Wang SL, Lin YC, Sheng GD, Lee JF (2009) Reduction of $\mathrm{Cr}(\mathrm{VI})$ by crop-residue-derived black carbon. Environ Sci Technol 43:8801-8806

Hua C, Zhang R, Bai F, Lu P, Liang X (2016) Removal of chromium(VI) from aqueous solutions using quarnized chitosan microspheres. Chin J Chem Eng 25(2):153-158. https://doi.org/10.1016/j.cjche .2016.08.024

Ingole NW, Vinchurkar SS, Dharpal SV (2014) Adsorption of oil from waste water by using human hair. J Environ Sci Comput Sci Eng Technol 3(1):207-2017

Kazakis N, Kantiranis N, Kalaitzidou K, Kaprara M, Mitrakas M, Frei R, Vargemezis G, Tsourlos P, Zouboulis A, Filippidis A (2017) Origin of hexavalent chromium in groundwater: the example of Sarigkiol Basin, Northern Greece. Sci Total Environ 593-594:552-566
Khambhaty Y, Mody K, Basw S, Jha B (2009) Biosorption of Cr(VI) onto marine Aspergillus iger: experimental studies and pseudo-second order kinetics. World J Microb Biotechnol 25:1413-1421

Khan AA, Muthukrishnan M, Guha BK (2010) Sorption and transport modeling of hexavalent chromium on soil media. J Hazard Mater 174(1-3):444-454

Khulbe KC, Matsuura T (2018) Removal of heavy metals and pollutants by membrane adsorption techniques. Appl Water Sci 8:19. https:// doi.org/10.1007/s13201-018-0661-6

Liu X, Shen F, Qi X (2019) Adsorption recovery of phosphate from aqueous solution by $\mathrm{CaO}$-biochar composites prepared from eggshell and rice straw. Sci Total Environ 666:694-702

Mahdavian L (2012) Effects of magnetic field, pH and retention time on the lead $\left(\mathrm{Pb}^{2+}\right)$ adsorption by modified human hair, goat hair and sheep wool. Afr J Microbiol Res 6(1):183-189

Mahdavian L (2014) Simulation of heavy metal removal by $\alpha$-keratin Nano-structure of Human hair from environment. J Environ Treat Technol 2(2):31-35

Manjuladevi M, Anitha R, Manonmani S (2018) Kinetic study on adsorption of $\mathrm{Cr}(\mathrm{VI}), \mathrm{Ni}$ (II), $\mathrm{Cd}(\mathrm{II})$ and $\mathrm{Pb}$ (II) ions from aqueous solutions using activated carbon prepared from Cucumismelo peel. Appl Water Sci. https://doi.org/10.1007/s13201-018-0674-1

McNeil S (2001) Heavy metal removal using wool filters. Asian Textila J. https://doi.org/10.13140/2.1.5059.6480

Meng X, Zhang G, Li N (2017) Bi24Ga2039 for visible light photocatalytic reduction of $\mathrm{Cr}(\mathrm{VI})$ : controlled synthesis, facet-dependent activity and DFT study. Chem Eng J 314:249-256

Mohamed A, Nasser WS, Osman TA, Topark MS, Muhammed M, Uheida A (2017) Removal of chromium(VI) from aqueous solutions using modified composite nanofibers. J Collod Interface Sci. https://doi.org/10.1016/j.jcis.2017.06.066

Mohan D, Singh KP, Singh VK (2005) Removal of hexavalent chromium from aqueous solution using low-cost activated carbons derived from agricultural waste materials and activated carbon fabric cloth. Ind Eng Chem 44:1027-1042

Nethaji S, Sivasamy A (2014) Removal of hexavalent chromium from aqueous solution using activated carbon prepared from walnut shell biomass through alkali impregnation processes. Clean Technol Environ Policy 16:361-368. https://doi.org/10.1007/s10098-013-0619-1

Park D, Yun YS, Park JM (2005a) Use of dead fungal biomass for the detoxification of hexavalent chromium : screening and kinetics. Process Biochem 40:2559-2565

Park D, Yun YS, Park JM (2005b) Use of dead fungal biomass for the detoxification of hexavalent Chromium : screening and kinetics. Process Biochem 40:2559-2565

Rajapaksha AU, Alam MdS, Chen N, Alessi DS, Igalavithana AD, Tsang DCW, Ok YS (2018) Removal of hexavalent chromium in aqueous solutions using biochar: chemical and spectroscopic investigations. Sci Total Environ 625:1567-1573

Saha R, Mukherjee K, Saha I, Ghosh A, Ghosh SK, Saha B (2013) Removal of hexavalent chromium from water by adsorption on mosambi (Citrus limetta) peel. Res Chem Intermed 3:2245-2257

Song D, Pan K, Tariq A, Azizullah A, Sun F, Li Z et al (2016) Adsorptive removal of toxic chromium from waste-water using wheat straw and Eupatorium adenophorumm. PLoS ONE 11(12):e01670737. https ://doi.org/10.1371/journal

Su M, Fang Y, Li B, Yin W, Gu J, Liang H, Li P, Wu J (2019) Enhanced hexavalent chromium removal by activated carbon modified with micro-sized goethite using a facile impregnation method. Sci Total Environ 647:47-56. https://doi.org/10.1016/j.scitotenv.2018.07.372

Tan TC, Chia CK, Teo CK (1985) Uptake of metal ions by chemically treated human hair. Water Res 19(2):157-162 
Tewari N, Vasudevan P, Guha BK (2005) Study on biosorption of Cr(VI) by Mucor hiemalis. Biochem Eng J 23:185-192

Varvala S, Kumari A, Dharanija B, Bhargava SK, Parthasarathy R (2016) Removal of thorium (IV) from aqueous solutions by deoiled karanja seed cake: optimization using Taguchi method, equilibrium, kinetic and thermodynamic studies. J Environ Chem Eng 4:405-417

Wang XS, Tmg YP, Tao SR (2008) Removal of Cr(VI) from aqueous solutions by the nonliving biomass of Alligator Weed : kinetics and equilibrium. Adsorption 14:823-830

Zhang J, Yin H, Chen L, Liu F, Chen H (2017) The role of different functional groups in a novel adsorption complexation-reduction multi-step kinetic model for hexavalent chromium retention by undissolved humic acid. Environ Pollut. https://doi.org/10.1016/j. envpol.2017.10.1200269-7491

Zhang H, Carrillo F, Lopez-Mesas M, Palet C (2018) Volarization of keratin biofibers for removing heavy metals from aqueous solutions. Text Res J. https://doi.org/10.1177/0040517518764008

Publisher's Note Springer Nature remains neutral with regard to jurisdictional claims in published maps and institutional affiliations. 